67. LH

Draft

Published in Journal of Church and State 41 (1999): 213-252

\title{
"A Most Mild and Equitable Establishment of Religion" John Adams and the Massachusetts Experiment
}

\author{
JOHN WITTE, JR. *
}

\begin{abstract}
Massachusetts was the last of the original 13 American states to disestablish religion, having been founded in the early seventeenth century as a bastion of Puritanism. The Massachusetts Constitution of 1780 moved part way toward disestablishment by guaranteeing freedom and equality to all peaceable private religions but also retaining what leading constitutional draftsman John Adams called a "mild and equitable establishment of religion." This consisted of (1) a ceremonial establishment, reflected in public religious language, symbols, rituals, and oaths supported by the state; (2) a moral establishment, reflected in the virtues and values to be taught in state schools and universities and exemplified by elected officials and other public figures; and (3) an institutional establishment, reflected in mandatory tithe payments, required Sunday worship, and other supports for Congregational churches.

Adams advocated this balance of a tempered religious freedom and a slender religious establishment as the best political compromise between hardline establishmentarians and radical separationists in the state. But this view also reflected Adams' own political and religious philosophy that too little religious freedom is a recipe for hypocrisy and impiety, while too much religious freedom is an invitation to depravity and license. Too firm a religious establishment breeds coercion and corruption, while too little religious establishment allows secular prejudices to become constitutional prerogatives. Somewhere between these extremes, Adams believed, a society must find its balance. This was a strikingly different view of religious freedom than the strict separation of church and state views advocated by Adams' long time friendly rival, Thomas Jefferson. The balance between freedom and establishment that Adams advocated was reflected in the 1780 Massachusetts constitution and was defended in a series of famous state cases authored by Chief Justice Theophilus Parsons. But in 1833, Massachusetts amended its constitution to outlaw the institutional establishment of religion, notably the state tithing system, even though the state retained its ceremonial and moral establishments.
\end{abstract}

Keywords: John Adams; Massachusetts; Establishment of Religion; Religious Liberty; Religious Rights; Freedom of Conscience; Free Exercise of Religion; Tithing; Sunday Worship; Oaths; Religious Corporations; Thomas Jefferson; Theophilus Parsons 


\section{TWo MOdels OF RELIGIOUS LIBERTY}

Thomas Jefferson once described the 1779 Bill for the Establishment of Religious Freedom in Virginia as a "fair" and "novel experiment" in religious liberty for all. ${ }^{1}$ This bill, declared Jefferson, defied the millennium-old assumptions of the West - that one form of Christianity must be established in a community, and that the state must protect and support it against all other religions. Virginia would no longer suffer such governmental prescriptions or proscriptions of religion. All forms of Christianity must now stand on their own feet and on an equal footing with the faiths of "the Jew and the Gentile, . . . the Mahometan, the Hindoo, and Infidel of every denomination."2 Their survival and growth must turn on the cogency of their word, not the coercion of the sword, on the faith of their members, not the force of the law. ${ }^{3}$

Jefferson's life-long friendly rival, John Adams, wrote with equal enthusiasm about the "completely successful" "political experiment" in religious liberty engineered by the 1780 Massachusetts Constitution. "[l]t can no longer be called in question," he wrote, that "authority in magistrates and obedience of citizens can be grounded on reason, morality, and the Christian religion, without [succumbing to] the monkery of priests or the knavery of politicians"-or other forms of "ecclesiastical or civil tyranny."4 The Massachusetts Constitution guarantees that "all men of all religions consistent with morals and property . . . enjoy equal liberty [and] security of property ... and an equal chance for honors and

* Jonas Robitscher Professor of Law and Ethics and Director of the Law and Religion Program, Emory University, Atlanta. Another version of this chapter appears in Journal of Church and State 41 (2) (1999): 213.

1 Thomas Jefferson, "Letter of November 21, 1808," in Saul K. Padover, ed., The Complete Jefferson, Containing His Major Writings (Freeport, NY: Books for Libraries Press, 1943), 538; id., "Notes on the State of Virginia (1781-1785)," Query XVII in ibid., 673-676. See discussion in Sidney E. Mead, The Lively Experiment: The Shaping of Christianity in America (New York, Harper \& Row, 1963), 55-71.

${ }^{2}$ Thomas Jefferson, Autobiography (1821), in The Complete Jefferson, 1119-1194, at 1147.

${ }^{3}$ See, e.g., Thomas Jefferson, Letter to Rev. Samuel Miller, January 23, 1808, in P.L. Ford ed., The Works of Thomas Jefferson (New York: G.P. Putnam, 1904-1905), 11:7. See further discussion in Thomas E. Buckley, "The Political Theology of Thomas Jefferson," in Merrill D. Peterson and Robert C. Vaughan, eds., The Virginia Statute for Religious Freedom: Its Evolution and Consequences in American History (Cambridge: Cambridge University Press, 1988), 75-108.

4 John Adams, A Defense of the Constitutions of Government in the United States of America (1787), preface, in J.F. Adams, ed., The Works of John Adams, 10 vols. (Boston: Little \& Brown, 1850-1856), 4:290297; and id., A Dissertation on the Canon and Feudal Law (1774), in ibid., 3:451. 
power." 5 Yet, at the same time, the Constitution institutes a "most mild and equitable establishment of religion" featuring special state protections and privileges for preferred forms of Christian piety, morality, and charity. ${ }^{6}$

Here are two models of religious liberty offered by two of the greatest luminaries of the American founding era. ${ }^{7}$ Both Jefferson and Adams were self-consciously engaged in a new experiment in religious liberty. Both started with the credo of the American Declaration of Independence which they drafted - that "all men are created equal" and that they have "certain unalienable rights." Both insisted upon bringing within the mantle of constitutional protection every recognized religion of the day-Christian and Jew, Muslim and Hindu, Infidel and Pagan alike. Both advocated guarantees of "essential rights and liberties of religion" for all. ${ }^{8}$ Both cast their views in enduring legal forms in 1779-Jefferson in his draft bill which became the law of Virginia seven years later, Adams in his draft Constitution which was ratified by the people of Massachusetts in 1780 .

Jefferson and Adams, however, cast these common principles into their own models of religious liberty, with their own distinctive legal emphases and applications.

Jefferson thought that true religious liberty required both the disestablishment and the free exercise of all religions. The state, he insisted, should give no special aid, support, privilege, or protection to any religion -through special tax subsidies and exemptions or through special criminal protections and special forms of religious incorporation. The state should predicate no laws or policies on explicitly religious grounds or arguments, or draw on the services of religious officials or bodies to discharge its functions. The state should refrain "from intermeddling . . . with religious institutions, their doctrines, discipline, or exercises ... and from the power of effecting any uniformity of time or matter among them." 9 The state should respect the liberty of conscience and free exercise of all its subjects, which

\footnotetext{
${ }^{5}$ Letter to Dr. Price, April 8, 1785, in ibid., 8:232. Elsewhere, Adams wrote that in Massachusetts, "there is, it is true, a moral and political equality of rights and duties among all the individuals and as yet no appearance of artificial inequalities of conditions. ... " Quoted in Frank Donovan, ed., The John Adams Papers (New York: Dodd, Mead \& Company, 1965), 181. In a letter of October 2, 1818 to Adrian van der Kemp, Adams again praised "freedom of religion" so long as it was "consistent with morals and property." Quoted by John R. Howe, Jr., The Changing Political Thought of John Adams (Princeton: Princeton University Press, 1966), $227 n$.

${ }^{6}$ Diary Entry, October 14, 1774, in J.F. Adams, ed., The Works of John Adams, 10 vols. (Boston: Little \& Brown, 1850-1856), 2:399 (referring to the congregational establishment of colonial Massachusetts, largely preserved in the 1780 Constitution).

7 On the relationship and influence of Jefferson and Adams, see Lester J. Cappon, ed., The AdamsJefferson Letters, 2 vols. (Chapel Hill: University of North Carolina Press, 1959) and John Murray Allison, Adams and Jefferson: The Story of a Friendship (Norman: University of Oklahoma Press, 1966).

${ }^{8}$ The phrase comes from a 1744 tract of Elisha Williams, The Essential Rights and Liberties of Protestants: A Seasonable Plea for The Liberty of Conscience, and the Right of Private Judgment in Matters of Religion, Without any Controul from Human Authority (Boston, 1744). John Adams also spoke of "our most essential rights and liberties." See "Instructions of the Town of Braintree to their Representative, in Adams, Works, 3:465.

9 Jefferson, Letter to Rev. Samuel Miller, Works, 11:7-9. He continued: "Fasting \& prayer are religious exercises. The enjoining them is an act of discipline. Every religious society has a right to determine for itself the times for these exercises, \& the objects proper for them, according to their own peculiar tenets. ... "
} 
are "the most inalienable and sacred of all human rights."10 "Almighty God hath created the mind free," Jefferson wrote. "[A]ll attempts to influence it by temporal punishments, or burthens, or by civil incapacitations, tend only to beget habits of hypocrisy and meanness, and are a departure from the plan of the holy author of our religion ...." "[N]o man shall be compelled to frequent or support any religious worship, place, or ministry whatsoever, nor shall be enforced, restrained, molested, or burthened in his body or goods, nor shall otherwise suffer, on account of his religious opinions or belief; but that all men shall be free to profess, and by argument to maintain, their opinion in matters of religion, and that the same shall in no wise diminish, enlarge, or affect their civil capacities."11 Such views, which Jefferson wrote into his famous 1779 Bill, would have a profound influence on the religious liberty experiment not only of Virginia, but eventually of the entire nation. ${ }^{12}$

Adams thought that true religious liberty required the state to balance the establishment of one "Publick religion"13 with the freedom of many private religions. On the one hand, he said, every polity must establish by law some form of public religion, some image and ideal of itself, some common values and beliefs to undergird and support the plurality of private religions. The notion that a state and society could remain neutral and purged of any religion was, for Adams, a philosophical fiction. Absent a commonly adopted set of values and beliefs, politicians would invariably hold out their private convictions as public ones. It was thus essential for each community to define the basics of its public religion. In Adams's view, the creed of this public religion was honesty, diligence, devotion, obedience, virtue, and love of God, neighbor, and self. ${ }^{14}$ Its icons were the Bible, the bells of liberty, the memorials of patriots, the Constitution. ${ }^{15}$ Its clergy were public-spirited ministers and

\footnotetext{
${ }^{10}$ Thomas Jefferson, "Freedom of Religion at the University of Virginia (October 7, 1822)," in The Complete Jefferson, 958. In ibid., 957, Jefferson called liberty of conscience and free exercise of religion "the most interesting and important to every human being."

${ }^{11}$ A Bill for Establishing Religious Freedom (1779), in The Complete Jefferson, 946-947.

12 See esp. Edwin S. Gaustad, Sworn on the Altar of God: A Religious Biography of Thomas Jefferson (Grand Rapids: Wm. Eerdmans, 1996).

${ }^{13}$ The phrase is from Benjamin Franklin, Proposals Relating to the Education of Youth in Pensilvania (1749), quoted and discussed in Martin E. Marty, "On a Medial Moraine: Religious Dimensions of American Constitutionalism," Emory Law Journal 39 (1990): 9, 16-17. The phrase became commonplace thereafter; in the nineteenth century, it was eventually transmuted into "civil religion." See Robert N. Bellah, The Broken Covenant: American Civil Religion in Time of Trial (New York: Harper and Row, 1975).

${ }^{14}$ See, e.g., John Adams, Letter to Zabdiel Adams, June 21, 1776, in Adams, Works, 4:194: "The only foundation of a free constitution is pure virtue." John Adams, Letter to Benjamin Rush, February 2, 1807, in John A. Schutz and Douglass Adair, eds., The Spur of Fame: Dialogues of John Adams and Benjamin Rush, 1805-1813 (San Marino, CA: The Huntington Library, 1966), 75-77, at 76: "I say then that national morality never was and never can be preserved without the utmost purity and chastity in women; and without national morality a republican government cannot be maintained." Letter to Benjamin Rush, August 28, 1811, in ibid., 191-195, at 192: "I agree with you that in sentiment that religion and virtue are the only foundations not only republicanism and of all free government but of social felicity under all governments and in all the combinations of civil society." In the same letter, Adams defended the "inculcation of 'national, social, domestic, and religious virtues'," "fidelity to the marriage bed," "the sanctification of the Sabbath," prohibitions "against ardent spirits, the multiplication of taverns, retailers, dram shops, and tippling houses . . . idlers, thieves, sots, and consumptive patients made for the physicians in those infamous seminaries. . . " "

15 See, e.g., Letter to Benjamin Rush, February 2, 1807, 75-76: "The Bible contains the most profound philosophy, the most perfect morality, and the most refined policy that ever was conceived upon earth. It is the most republican book in the world. and therefore I will still revere it." See also Letter to Mrs. Adams, July 3 1776, in Adams, Works, 9:419-420 regarding the celebration of national symbols and events.
} 
religiously-devout politicians. ${ }^{16}$ Its liturgy was the public proclamation of oaths, prayers, songs, and election and Thanksgiving Day sermons. ${ }^{17}$ Its policy was state appointment of chaplains for the legislature, military, and prison, state sanctions against blasphemy, ${ }^{18}$ sacrilege, and iconoclasm, state sponsorship of religious societies, schools, and charities. ${ }^{19}$

On the other hand, Adams argued, every civil society must countenance a plurality of forms of religious exercise and association-whose rights could be limited only by the parallel rights of juxtaposed religions, the concerns for public peace and security, and the duties of the established public religion. The notion that a state could coerce all persons into adherence and adherents to a common public religion alone was, for Adams, equally a philosophical fiction. Persons would make their own private judgments in matters of faith, for the rights of conscience are "indisputable, unalienable, indefeasible, [and] divine."20

Moreover, the maintenance of religious pluralism was essential for the protection of religious and other forms of liberty. As Adams put it in a letter to Jefferson: "Roman Catholics, English Episcopalians, Scotch and American Presbyterians, Methodists, Moravians, Anbabtists [sic], German Lutherans, German Calvinists, Universalitists, Arians, Priestlyians, Socinians, Independents, Congregationalists, Horse Protestants and House Protestants, Deists and Atheists and Protestants qui ne croyent rien [who believe nothing] are ... [n]ever the less all Educated in the general Principles of Christianity: and the general Principles of English and American liberty."21 "Checks and balances, Jefferson"-in the political as well as the religious sphere-Adams went on in another letter, "are our only Security, for the progress of Mind, as well as the Security of Body. Every Species of these

\footnotetext{
${ }^{16}$ See esp. Massachusetts Constitution (1780), Art. XVIII and notes thereon in Adams, Works, 4:227-228.

${ }^{17} \mathrm{Ibid}$., See also Letter to Benjamin Rush, June 12, 1812, in Spur of Fame, 224-226, at 224 on Thanksgiving sermons.

18 Late in this life, Adams expressed regret about blasphemy laws. In a letter of January 23, 1825 to Jefferson, he wrote: "We think ourselves possessed, or, at least, we boast that we are so, of the liberty of conscience on all subjects, and of the right of free inquiry and private judgments in all cases, and yet how far are we from these exalted privileges in fact! There exists, I believe, throughout the whole Christian world, a law which makes it a blasphemy to deny or to doubt the divine inspiration of all the books of the Old and New Testament. . . . In America, it is not much better; even in our own Massachusetts, which I believe, upon the whole, is as temperate and moderate in religious zeal as most of the States, a law was made in the latter end of the last century, repealing the cruel punishments of the former laws, but substituting fine and imprisonment upon all blasphemers. . . . I think such laws a great embarrassment, great obstructions to the improvement of the human mind. ... I wish they were repealed. The substance and essence of Christianity, as I understand it, is eternal and unchangeable, and will bear examination forever. . . " Adams, Works, 10:415-416.

${ }^{19}$ For Adams' earlier views on this, see esp. A Dissertation on the Canon and Feudal Law (1774), in ibid., 3:448-464; and Thoughts on Government Applicable to the Present State of the Colonies (1776), in ibid., 4:193-209. For later formulations, see Howe, Changing Political Thought of John Adams, $227 \mathrm{ff}$.

20 See his Dissertation on the Canon and Feudal Law, Adams, Works, 3:452-456. Such views were commonplace in Massachusetts. See, e.g., Williams, Essential Rights and Liberties, 7-8: "Every man has an equal right to follow the dictates of his own conscience in the affairs of religion. Every one is under an indispensable obligation to search the Scriptures for himself . . . and to make the best use of it he can for his own information in the will of God, the nature and duties of Christianity. As every Christian is so bound; so he has the inalienable right to judge of the sense and meaning of it, and to follow his judgment wherever it leads him; even an equal right with any rulers be they civil or ecclesiastical." See further Ronald M. Peters, Jr., The Massachusetts Constitution of 1780: A Social Compact (Amherst: The University of Massachusetts Press, 1978), 79-81.

21 John Adams, Letter to Thomas Jefferson, June 28, 1813, Adams-Jefferson Letters, 338-340, at 339-340.
} 
Christians would persecute Deists, as [much] as either Sect would persecute another, if it had unchecked and unballanced Power. Nay, the Deists would persecute Christians, and Atheists would persecute Deists, with as unrelenting Cruelty, as any Christians would persecute them or one another. Know thyself, Human nature!"22

The 1780 Massachusetts Constitution, which John Adams in large measure drafted, struck this balance between the establishment of one public religion and the freedom of all private religions. The Constitution's most controversial provisions on religious test oaths and tithes were outlawed by amendments of 1821 and 1833. The harder edges of religious establishment were further blunted by judicial interpretation and legislative innovation. ${ }^{23}$ But the basic model of religious liberty, constructed by John Adams and his colleagues, has remained unchanged in fundamentals until today. Over the past two centuries, this Massachusetts model has gathered its own substantial following, not only among other New England states but also among various courts interpreting the First Amendment to the United States Constitution. ${ }^{24}$ Indeed, while Jefferson's model lies at the heart of modern theories of separationism and religious individualism, Adams's model lies at the heart of modern theories of accommodationism and religious communitarianism.

In this Article, I explore Adams' model of religious liberty, as it was adopted and adapted in Massachusetts. I first summarize the events and texts leading to the formation of the Massachusetts Constitution. I then explore the juxtaposed provisions on the establishment of a public religion and the freedom of private religions, and the considerable controversy surrounding the definition and defense of the same. The Conclusion harvests some of the lessons from the Massachusetts experience for the ongoing experiment in religious liberty in America.

\section{The Formation OF the MAssachusetts CONSTITUtion}

The Massachusetts Constitution of 1780 is "the oldest written organic law still in operation anywhere in the world. ..."25 The original document, running thirty-three $6 \times 9$

\footnotetext{
22 John Adams, Letter to Thomas Jefferson, June 25, 1813, in ibid., 333-335, at 334. Jefferson had long maintained similar views. See, e.g. Notes on the State of Virginia, query 17: "Difference of opinion is advantageous in religion," Thomas Jefferson wrote. "The several sects perform the office of a censor morum over each other." The Complete Jefferson, 675-676.

${ }^{23}$ For a good summary, see Jacob C. Meyer, Church and State in Massachusetts From 1740-1833, repr. ed. (New York: Russell \& Russell, 1968) and the magisterial study of the religious liberty of dissenters in William C. McLoughlin, New England Dissent 1630-1833, 2 vols. (Cambridge: Harvard University Press, 1971).

${ }^{24}$ For comparable provisions in the Constitutions of New Hampshire (1784), Connecticut (1818), and Maine (1820), see Chester J. Antieau et al., Religion Under the State Constitutions (Brooklyn: Central Book Co., 1965), 209-211, 181-182, 194-195.

${ }^{25}$ Robert J. Taylor, Construction of the Massachusetts Constitution (Worcester, MA: American Antiquarian Society, 1980), 317. Among countless overviews, see esp. the classic of Samuel Eliot Morison, A History of the Constitution of Massachusetts (Boston: Wright \& Potter, 1917). For principal primary texts, see Oscar and Mary Handlin, eds., The Popular Sources of Political Authority: Documents on The Massachusetts Constitution of 1780 (Cambridge: Harvard University Press, 1966) and Robert J. Taylor, ed., Massachusetts, Colony to
} 
printed pages, has a preamble and two main parts. Part One is a Declaration of Rights of the Inhabitants of the Commonwealth in thirty articles. Part Two is a Frame of Government in six chapters. The Constitution has been amended 117 times since its ratification. But the original terms and terminology remain mostly in place.

\section{A. The FAILed 1778 Constitution}

The 1780 Constitution replaced the 1691 Provincial Charter, issued by the British Crown as the organic law of the colony of Massachusetts-Bay. The Charter had ruled continuously until June 17, 1774, when the last General Court called by the royal governor adjourned. During the rumblings of the American revolution in 1774 and 1775, the colonists formed three successive Provincial Congresses. In July, 1775, they elected their own representative General Court-for the first time without royal permission and without compliance with the procedures of the Provincial Charter. The General Court, in turn, elected a Council and vested it with legislative and executive powers, and with appellate jurisdiction over the lower courts. The Council was transformed into a constitutional convention in June, 1777. John Adams, who was serving first in the Continental Congress then in Europe at the time, did not participate in these convention or ratification debates.

On February 28, 1778, the Council submitted a draft constitution for popular ratification. The draft was largely a barebones blueprint of government. It seemed calculated more to respond to immediate concerns of representation of the townships than to the enduring needs of the commonwealth. Most of its 36 articles concerned the rights and restrictions of popular suffrage and regional representation, and the powers and procedures of the executive, legislative, and judicial offices of the commonwealth. Article XXXII simply confirmed as presumptively constitutional all colonial laws, including the laws on religion"such parts only excepted as are repugnant to the rights and privileges contained in this Constitution." Few such "rights and privileges" were set forth. Article XXXII guaranteed for all "the inestimable right of trial by jury." Two other Articles confirmed the traditional privileges and protections of Protestants: Article XXIX stated: "No person unless of the Protestant religion shall be Governor, Lieutenant Governor, a member of the Senate or of the House of Representatives, or hold any judiciary employment within this State." Article XXXIV provided: "The free exercise and enjoyment of religious profession and worship shall forever be allowed to every denomination of Protestants within this State."26 For the rest, the document was silent on religious and civil rights.

The 1778 draft constitution was roundly rejected by the people of Massachusetts. A leading opponent of ratification was Theophilus Parsons, a young lawyer from Newburyport, who would later figure prominently in the formation and enforcement of the religion clauses of the 1780 Massachusetts Constitution. In his Essex Result, a pamphlet that both galvanized and systematized popular objections to the draft constitution, Parsons singled out for special criticism the absence of a declaration of civil rights and the deliberate abridgement of religious rights. "[T]he rights of conscience are not therein clearly defined

Commonwealth: Documents on the Formation of its Constitution (Chapel Hill: University of North Carolina Press, 1961).

${ }^{26}$ Reprinted in Handlin, Popular Sources, 190-201. 
and ascertained," he wrote. "We have duties, for the discharge of which we are accountable to our Creator and benefactor, which no human power can cancel. What those duties are, is determinable by right reason, which may be, and is called, a well-informed conscience. What this dictates as our duty, is so; and that power which assumes a controul over it, is an usurper; for no consent can be pleaded to justify the controul, as any consent in this case is void." Moreover, "the free exercise and enjoyment of religious worship is there said to be allowed to all protestants of the State, when in fact, that free exercise and enjoyment is the natural and uncontrollable right of every member of the State." 27

\section{B. "A Company of EARThly Hosts" on Religious Liberty}

On February 20,1779, the House of Representatives called for a new constitutional convention, and "lawfully warned" the "Selectmen of the several Towns" to deliberate their concerns and to instruct their delegates. ${ }^{28}$ The constitutional protection of religious liberty figured prominently in these deliberations and instructions, with the townships revealing wide-ranging concerns. The township of Stoughton, for example, instructed its delegate:

You are directed to use and employ your assiduous Endeavours as Soon as the Convention meets that a Bill of Rights be in the first place compiled, wherein the inherent and unalienable Rights of Conscience and all those alienable rights are not necessary to be given up in the hands of government . . . shall be clearly, fully and unequivocally defined and explained. . . . ${ }^{29}$

The delegate of Pittsfield came armed with a recommended provision:

every man has an unalienable right to enjoy his own opinion in matters of religion, and to worship God in that manner that is agreeable to his own sentiments without any control whatsoever, and that no particular mode or sect of religion ought to be established but that every one be protected in the peaceable enjoyment of his religious persuasion and way of worship. . . . 30

The township of Sandisfield instructed its delegate to seek protection of both local control over the establishment of Protestantism and guarantees of toleration for other faiths:

[Y]ou will Endeavour in the forming of the Constitution that the Free Exercise of religious principles or Profession, worship and Liberty of Conscience shall be for ever Secured to all Denominations of Protestants -- and Protestant Disenters of all

27 The Essex Result (April 29, 1778), reprinted in ibid., 324-365, at 326, 330.

${ }^{28}$ Resolve on the Question of a Constitution, February 20, 1779, reprinted in ibid., 383-384.

${ }^{29}$ Reprinted in ibid., 423.

${ }^{30}$ Reprinted in Taylor, ed., Massachusetts, Colony to Commonwealth, 118. 
Denominations within the State, without any Compulsion whatever. Always allowing the Legislative Body of this State the Power of Toleration to other Denominations of Christians from time to time as they Shall see Cause, at the same time, Reserving to our Selves, the Right of Instructions to our Representatives Respecting Said Toleration as well as in other Cases. . . . ${ }^{31}$

Delegates who were not furnished with explicit directives from the townships could draw inspiration and instruction from the scores of sermons and pamphlets on the constitutional protection of religious liberty that circulated in Massachusetts in the later 1770 s. $^{32}$ The intense volume and volatility of these writings led Adams later to quip: "A whole company of earthly hosts hath debated these heavenly things with an hellish intensity." 33

The oft-printed pamphlet, Worcestriensis Number IV of 1776, offered a typical moderate position, defending both the generous toleration of all religions and the gentle establishment of the Protestant religion. The pamphlet began with a defense of liberty of conscience and religious pluralism.

In a well regulated state, it will be the business of the Legislature to prevent sectaries of different denominations from molesting and disturbing each other, to ordain that no part of the community shall be permitted to perplex and harass the other for any supposed heresy, but that each individual shall be allowed to have and enjoy, profess and maintain his own system of religion, provided it does not issue in overt acts of treason undermining the peace and good order of society. To allow one part of a society to lord it over the faith and consciences of the other, in religious matters, is the ready way to set the whole community together by the ears. ${ }^{34}$

State officials thus had an important role to keep the common peace among the plural faiths of the community.

State officials were also empowered, however, "to give preference to that profession of religion which they take to be true," the author of Worcestriensis insisted. State officials could not command citizens to conform to this preferred religion, nor could they subject nonconformists "to pains, penalties, and disabilities."

\footnotetext{
${ }^{31}$ Reprinted in Handlin, Popular Sources, 419.

32 See Peters, The Massachusetts Constitution, 24-30; Barry Shain, The Myth of American Individualism: The Protestant Origins of American Political Thought (Princeton: Princeton University Press, 1994), 193-240.

${ }^{33}$ Adams, Works, 8:55

${ }^{34}$ Worcestriensis, Number IV (1776), in Hynemann and Lutz, eds., American Political Writing, 449-454, at 450 (emphases omitted)
} 
The establishment contended for in this disquisition, is of a different kind, and must result from a different legal Procedure. It must proceed only from the benign principles of the legislature from an encouragement of the General Principles of religion and morality, recommending free inquiry and examination of the doctrine said to be divine; using all possible and lawful means to enable its citizens to discover the truth, and to entertain good and rational sentiments, and taking mild and parental measures to bring about the design; these are the most probable means of bringing about the establishment of religion. ${ }^{35}$

State officials could thus "exert themselves in favor of one religion over the other." They could extract religious oaths from their officials, "for there is no stronger cement of society." They could punish profanity, blasphemy, and debauchery, all of which "strike a fatal blow at the root of good regulation, and well-being of the state." They could provide "able and learned teachers [that is, ministers] to instruct the people in the knowledge of what they deem the truth, maintaining them by the public money, though at the same time they have no right in the least degree to endeavor the depression of professions of religious denomination." 36

Phillips Payson, an influential congregationalist minister, laid greater stress on the need for a public religious establishment, warning against "dangerous innovations" in the inherited colonial patterns. To be sure, Payson wrote, "religious or spiritual liberty must be accounted the greatest happiness of man, considered in a private capacity." ${ }^{37}$ But, he insisted:

[R]eligion, both in rulers and people [is] . . . of the highest importance to . . . civil society and government, ... as it keeps alive the best sense of moral obligation, a matter of such extensive utility, especially in respect to an oath [of office], which is one of the principal instruments of government. The fear and reverence of God, and the terrors of eternity, are the most powerful restraints upon the minds of mind; and hence it is of special importance in a free government, the spirit of which being always friendly to the sacred rights of conscience, it will hold up the Gospel as the great rule of faith and practice. Established modes and usages in religion, more especially the public worship of God, so generally form the principles and manners of a people that changes or alterations in these, especially when nearly conformed to spirit and simplicity of the

\footnotetext{
${ }^{35}$ Ibid., 452 (emphases and capitalization omitted).

${ }^{36} \mathrm{Ibid}$., 452-453 (emphases omitted). Samuel West, an influential Congregationalist preacher in Dartmouth argued similarly. Samuel West, A Sermon Preached Before the Honorable Council . . of the MassachusettsBay in New England (Boston: John Gill, 1776), reprinted in J.W. Thornton, The Pulpit of the American Revolution (Boston: Gould and Lincoln, 1860), 259-322, at 297-299.

${ }^{37}$ Phillips Payson, "Election Sermon of 1778," reprinted in Hynemann and Lutz, eds., American Political Writing, 523-538, and in Thornton, The Pulpit of the American Revolution, 323-353. I am using the first version.
} 
Gospel, may well be deemed very dangerous experiments in government. For this, and other reasons, the thoughtful and wise among us trust that our civil fathers, from a regard to gospel worship and the constitution of these churches, will carefully preserve them, and at all times guard against every innovation that might tend to overset the public worship of God. ... Let the restraints of religion once broken down, as they infallibly would be, by leaving the subject of public worship to the humours of the multitude, and we might well defy all human wisdom and power, to support and preserve order and government in the State. ... ${ }^{38}$

Isaac Backus, the most learned Baptist voice of the day, laid greater stress on the protection of private religious liberty, warning against the "hypocrisy" and "futility" of public religious establishments. In a series of pamphlets in the 1770s, he charged that the Massachusetts authorities were "assuming a power to govern religion, rather than being governed by it."39 "I am as sensible of the importance of religion and of the utility of it to human society, as Mr. Payson is," Backus wrote. "And I concur with him that the fear and reverence of God and the terrors of eternity are the most powerful restraints upon the minds of men. But I am so far from thinking with him that these restraints would be broken down if equal religious liberty was established. . . "40 Look at the long history of Christian establishment, Backus wrote. It has led not to pure religion; instead "tyranny, simony, and robbery came to be introduced and to be practiced under the Christian name." 41 Look at the city of Boston, which has had no religious establishment of late; there religion, state, and society all flourish without fail. ${ }^{42}$ Look at the principles of the American revolution; "all America is up in arms against taxation without representation." But just as certainly as we Americans were not represented in the British Parliament, so we religious dissenters are not represented among the established civil authorities. Yet we are still subject to their religious taxes and regulations. ${ }^{43}$ Look at the principles of the Bible:

\footnotetext{
${ }^{38}$ Ibid., 528-530. A bit later, Payson declared grandly: "The eyes of the whole world are upon us in these critical times, and, what is yet more, the eyes of Almighty God. . . . With diligence let us cultivate the spirit of liberty, of public virtue, of union and religion, and thus strengthen the hands of government and the great pillars of the state. Our own consciences will reproach us and the world condemn us if we do not properly obey, respect, and reverence the government of our choosing." Ibid, 538.

${ }^{39}$ Isaac Backus, Government and Liberty Described (1778), reprinted in William G. McLoughlin, ed., Isaac Backus on Church, State, and Calvinism: Pamphlets, 1754-1789 (Cambridge: Harvard University Press, 1968), 345-369, at 351.

40 Ibid., 358. See also Isaac Backus, Policy as Well as Honesty, Forbids the Use of Secular Force in Religious Affairs (1779), reprinted in McLoughlin, ed., Backus, 367-383: "The necessity of a well-regulated government in civil states is acknowledged by all, and the importance and benefit of true Christianity in order thereto is no less certain."

${ }^{41}$ Ibid., 373-374.

42 lbid., 357.

${ }^{43} \mathrm{Ibid}$. See further ibid., 361: "Many of the Baptists of this State have long been convinced, that a giving in the annual certificates required by the ruling party as the condition of our exemption from TAXES to their ministers contains an explicit acknowledgment of a power assumed by man which in reality belongs only to God. And in our Appeal to the Public, printed in Boston five years ago, we have given the particular reasons why we cannot in conscience perform that condition. Yet only because we have refused to wrong our
} 
God has expressly armed the magistrate with the sword to punish such as work ill to their neighbors, and his faithfulness in that work and our obedience to such authority, is enforced [by the Bible]. But it is evident that the sword is excluded from the kingdom of the Redeemer.... [I]t is impossible to blend church and state without violating our Lord's commands to both. His command to the church is, Put away from among yourselves that wicked person. His command to the state is, Let both grow together until the harvest. But it has appeared for these thousand years that pure Gospel discipline in the church is very little if at all known in state establishments of religion and that instead of letting conformists thereto, and dissenters therefrom, grow together to enjoy equal worldly privileges, the sword has been employed to root up, and to prepare war against all such as put not into the mouths of the established teachers who are the means of upholding such rulers pervert all equity. ${ }^{44}$

\section{ReLIGION AND the Formation OF the 1780 Constitution}

Such were some of the discordant sentiments on religious liberty on the eve of the second constitutional convention in Massachusetts. It was clear that the congregationalists would insist on some form of establishment. As John Adams put it: "We might as soon expect a change in the solar system as to expect they would give up their establishment." ${ }^{45}$ It was equally clear that religious dissenters, and more liberal congregationalists, would insist on the disestablishment and free exercise of religion -- particularly since several other states had already granted such liberties. ${ }^{46}$ Some via media between these competing perspectives would have to be found.

On September 1, 1779, 293 delegates gathered in Boston to draft a new constitution. ${ }^{47}$ Included in the convention were most of the leading lights of Massachusetts-39 merchants, 31 lawyers, 22 farmers, 21 clergy, 18 physicians, and 18 magistrates. ${ }^{48}$ Most delegates were Puritan Congregationalists. Five delegates were Baptists. A few others were suspected to be quiet Quakers, Anglicans, or Catholics. ${ }^{49}$

consciences in that respect our people in various places have been taxed from year to year to [support] pedobaptist ministers."

44 Ibid., 375.

${ }^{45}$ As reported by Isaac Backus, and quoted by McLoughlin, ed., Backus on Church and State, 12, and discussed in McLouglin, New England Dissent, 558-568. In his Diary of 1774, Adams records this quip as a reply not to Backus but to Israel Pemberton, a Pennsylvania Quaker: "I knew they might as well turn the heavenly bodies out of their annual and diurnal courses, as the people of Massachusetts at the present day from their meeting-house and Sunday laws." Adams, Works, 2:399.

${ }^{46}$ See sources and discussion in James H. Hutson, Religion and the Founding of the American Republic (Washington: Library of Congress, 1998), 59-74.

${ }^{47}$ The delegates did not attend all sessions; the highest recorded vote on any issue was 247 . Morison, "The Struggle," 356.

${ }^{48}$ Peters, The Massachusetts Constitution, 24.

49 Ibid., 23-31; McLoughlin, ed., Backus, 386. 
On September 4, 1779, the constitutional convention elected a committee of 27 members-later augmented by four others-to prepare a draft declaration of rights and a frame of government. This committee, in turn, delegated the drafting to a three member subcommittee of James Bowdoin, Samuel Adams, and John Adams. John Adams, widely respected for his legal and political acumen, was selected to push the pen for the subcommittee. He completed his work in mid-October. First the three member subcommittee, then the full drafting committee made some modest alterations to Adam's draft. ${ }^{50}$ The committee's draft was submitted to the full convention for debate on October 28, 1779.51 The convention debated the draft constitution until November 12; Adams participated in this session of the debate, but set sail immediately thereafter for France. The convention completed its deliberations from January 27 to March 1, 1780, now without Adams.

The convention chose to vote separately on each article of the declaration of rights, and each chapter of the frame of government in Adams's draft constitution. Ten provisions of the draft touched on matters of religion and religious liberty -- the preamble, Articles I, II, III, VII, and XVIII of the Declaration of Rights, and Chapters I, II, V and VI of the Frame of Government. Five of these ten provisions were approved without comment, controversy, or change.

Four of the remaining provisions on religion in Adams's draft garnered modest discussion and revision in the constitutional convention. In Article II, Adams had written: "It is the Duty of all men in society, publickly, and at stated seasons to worship the SUPREME BEING, the great Creator and preserver of the Universe." After brief discussion, the convention amended this to say: "It is the right as well as the duty of all men" so to worship. ${ }^{52}$ In Chapter I of the Frame of Government, Adams had stipulated that no person was eligible to serve in the House of Representatives, "unless he be of the Christian religion." The convention struck this provision-though it left untouched the next Chapter, where Adams imposed the same religious conditions upon the offices of Governor and Lieutenant Governor. ${ }^{53}$ In the same spirit, Adams had proposed in Chapter VI that all state officials and appointees swear the same religious test oath: "that I believe and profess the Christian religion and have a firm persuasion of its truth." The convention insisted on a slightly reworded such oath only for elected executive and legislative officers, requiring all others simply to declare their "true faith and allegiance to this Commonwealth." After several delegates argued for a more specifically Protestant test oath, the convention added to both oaths a transparently anti-Catholic provision, which Adams and others later protested without success: "I do renounce and abjure all allegiance, subjection and obedience to. . . every. . . foreign Power whatsoever: And that no foreign . . . Prelate . . . hath, or ought to have, any jurisdiction, superiority, pre-eminence, authority, dispensing, or other power, in

50 See letter of June 7, 1780 to Edmund Jennings, quoted in Adams, Works, 4:216.

51 The draft is reprinted in Adams, Works, 4:213-267.

${ }^{52}$ Adams, Works, 4:221.

${ }^{53}$ Chapter I, Section III. See Chapter II, Section II (requiring that the governor "shall be of the Christian religion"); Section III (requiring that the lieutenant governor "shall be qualified, in point of religion"). See Adams, Works, 4:241, 242, 245, 251. 
any matter, civil, ecclesiastical or spiritual within this Commonwealth. . . "54 Adams's draft oath had concluded: "So help me God," but had then made specific provision "that any person who has conscientious scruples relative to taking oaths, may be admitted to make solemn affirmation" by other means. After some delegates protested that so generic an exemption might be subject to abuse, the convention restricted the exemption to Quakers only. ${ }^{55}$ An 1821 amendment to the Constitution expunged the religious test oath for political office altogether. ${ }^{56}$

Article III, stipulating the payment of religious taxes in support of congregational ministers, was by far "the most controversial one in the whole draft constitution," occupying more than a third of the convention debate. ${ }^{57}$ Given the heat of the religious liberty debate on the eve of the convention, the controversy was not unexpected. Adams chose not to draft Article III himself. "I could not satisfy my own Judgment with any Article that I thought would be accepted," he later wrote. "Some of the Clergy, or older and graver Persons than myself would be more likely to hit the Taste of the Public."58 Adams did, however, approve without reservation a draft that came out of the full drafting committee and, as we shall see, incorporated establishment provisions elsewhere in the constitution.

The first draft of Article III, submitted to the convention on October 28, 1779, read thus:

Good morals, being necessary for the preservation of civil society; and the knowledge and belief of the being of GOD, His providential government of the world, and of a future state of rewards and punishment, being the only true foundation of morality, the legislature hath, therefore, a right, and ought to provide, at the expense of the subject, if necessary, a suitable support for the public worship of GOD, and of the teachers of religion and morals; and to enjoin upon all the subjects an attendance upon these instructions, at stated times and seasons; provided there be any such teacher, on whose ministry they can conscientiously attend.

All monies, paid by the subject of the public worship, and of the instructors in religion and morals, shall, if he requires it, be uniformly applied to the support of the teacher or teachers of his own religious denomination, provided there be any on whose

\footnotetext{
${ }^{54}$ See Chapter VI, Art. I and Journal, 97, 109-110 (summarizing debates on February 10, 14, and 15, 1780 about the same).

${ }^{55}$ Chapter VI, Article I, with drafts in Adams, Works, 4:260-266.

${ }^{56}$ Amendment, Art. VI (1821) required the following oath for all officers: "I A.B. do solemnly swear that I will bear true faith and allegiance to the Commonwealth of Massachusetts, and will support the Constitution thereof. So help me GOD." Quakers were again excused from the oath. Amendment, Art. VII (1821) underscored this: "No oath, declaration or subscription, excepting the oath of the previous Article," was required of executive or legislative officers.

${ }^{57}$ Taylor, Construction, 331.

${ }^{58}$ Letter to William D. Williamson (February 25, 1812), quoted in Adams, Works, 4:222n.
} 
instructions he attends; otherwise it may be paid towards the support of the teacher or teachers of the parish or precinct in which the said moneys are raised. ${ }^{59}$

The first paragraph of this draft Article III, stipulating the necessity and utility of public worship and religious instruction, was a common sentiment and not particularly controversial. The second paragraph, however, mandating the collection of religious tithes to support the same, was a matter of great controversy.

It takes a bit of historical imagination and explication to appreciate the controversy over state collection of church tithes. Article III was designed to raise to constitutional status a colonial pattern of church-state relations, introduced by a law of 1692, and amended several times thereafter. ${ }^{60}$ This law blended church and state for purposes of taxation. It designated one territory as both a "parish" and a "township" under the authority of one city council. (In large townships that had more than one church, the multiple "parishes" were called "precincts," and each of these likewise was subject to the same council's authority.) To be a member of the township was automatically to be a member of a parish (or precinct). Each of the c. 290 parishes/townships in Massachusetts was required to have at least one congregationalist "teacher of religion and morality" (that is, a minister). This minister would lead the local community not only in public worship but often in education and charity as well. The community was required to provide him with a salary, sanctuary, and parsonage. Funds for this came from special religious taxes (usually called tithes, sometimes called church, parish, or religious rates). These were collected from all subjects in the township, who were by statutory definition also members of the parish. ${ }^{61}$

This tithing system worked rather well when all subjects within the same township were also active members of the same church. It did not work so well for persons who were religiously inactive, or were members of a non-congregationalist church, whether Baptist, Quaker, Anglican, or Catholic. As the number of such dissenting churches grew within the townships of Massachusetts, so did the protests to paying these mandatory taxes in support of the congregationalist ministers and churches. During the eighteenth century, colonial courts eventually carved out exceptions for some religious dissenters, allowing them to pay their tithes to support their own dissenting ministers and churches. Such dissenters, however, were required to register each church as a separate religious society, and to demonstrate their own faithful attendance at the same. Not all dissenting churches were able or willing to meet the registration requirements, and not all townships cooperated in granting the registrations or tithe exemptions. ${ }^{62}$ If the dissenting church was too small to have its own full-time minister, registration was routinely denied or rescinded. If the dissenting church was conscientiously opposed to legal incorporation and registration, as were Baptists after 1773, their members could not be exempt from taxation. If a member of

\footnotetext{
${ }^{59}$ Reprinted in ibid., 4:221-222; a slightly reworded version appears in the Journal, Appendix II, at 193.

${ }^{60}$ Acts and Resolves, Public and Private, of the Province of Massachusetts Bay. . . . (Boston: Government Printer, 1869-1922), 1:62-63.

61 See sources and discussion in my "Tax Exemption of Church Property: Historical Anomaly or Valid Constitutional Practice?" Southern California Law Review 64 (1991): 363-415, at 368-380.

62 Samuel Eliot Morison, "The Struggle over the Adoption of the Constitution of Massachusetts," 1780, Massachusetts Historical Society Proceedings 50 (1916-1917): 353-412, at 370.
} 
a registered dissenting church was too lax in his attendance of public worship, he could still be denied exemption from the congregationalist tithe. And if a town treasurer was too pressed for revenue, or too prejudiced against a certain group, he could refuse to give dissenting ministers their share of the tithes. In many of these cases, the Massachusetts courts proved notably churlish in granting standing, let alone relief, to groups or individuals who protested such inequities. ${ }^{63}$

It was this century-long system of religious taxes that the cryptic provisions of Article III were designed to perpetuate. And it was this feature of the inherited tradition of religious establishment that caused such controversy at the convention. The initial reaction to the draft of Article III was so heated that convention members voted to put off debate until November 1. They also voted to suspend the rule that no member could speak twice to the same issue, without requesting special privilege from the chair. Rancorous debate over the Article broke out immediately on November 1 -some condemning the provision as a "too pale an approximation of a proper establishment," others calling for abolition of the Article altogether, still others decrying the insufficient recognition of the concessions that dissenters had arduously won over the years. When matters deadlocked on November 3, the delegates appointed a seven member ad hoc committee of distinguished delegates, chaired by the Baptist delegate, Rev. Noah Alden of Bellingham, to redraft the controversial Article III. ${ }^{64}$ On November 6, this ad hoc committee put a new draft Article III before the convention that spelled out the prevailing religious tax system in more detail. This new draft was debated intermittently for the next four days, and modest word changes were approved. ${ }^{65}$ On November 10, a motion to abolish the Article altogether was defeated. A slightly amended draft of the Article was passed the following day. The final text of Article III reads thus:

As the happiness of a people, and good order and preservation of civil government, essentially depend upon piety, religion, and morality; and as these cannot be generally diffused through a Community, but by the institution of publick Worship of God, and of public instructions in piety, religion, and morality: Therefore, to promote the happiness and to secure the good order and preservation of their government, the people of this Commonwealth have a right to invest their legislature with power to authorize and require ... the several Towns, Parishes precincts and other bodies politic, or religious societies, to make suitable provision, at their own Expence, for the institution of the Public worship of GOD, and for the support and maintenance of public protestant teachers of piety, religion and morality, in all

63 See details in John D. Cushing, "Notes on Disestablishment in Massachusetts, 1780-1833," William \& Mary Quarterly, 3d ser. 26 (1969): 169-190; McLoughlin, New England Dissent, 547-565; Meyer, Church and State in Massachusetts, 32-89.

64 Journal, 38-40. Other members included Theophilus Parsons (later Chief Judge of the Massachusetts Supreme Juridical Court), Robert Treat Paine (Judge of the same Court), Samuel Adams (future Governor of Massachusetts), Caleb Strong (also future Governor), Timothy Danielson (leading patriot from Western Massachusetts), and David Sanford (pastor of the Second Congregational Church in Medway).

65 Ibid., 43. 
causes which provision shall not be made Voluntarily.- And the people of this Commonwealth have also a right to, and do, invest their legislature with authority to enjoin upon all the Subjects an attendance upon the instructions of the public teachers aforesaid, at stated times and seasons, if there be any on whose instructions they can Conscientiously and conveniently attendPROVIDED, notwithstanding, that the several towns, parishes, precincts, and other bodies politic, or religious societies, shall, at times, have the exclusive right of electing their public Teachers, and of contracting with them for their support and maintenance.-And all monies, paid by the Subject of the support of the public teacher or teachers of his own religious sect or denomination, provided there be any on whose institution he attends; otherwise it may be paid towards the support of the teacher or teachers of the parish or precinct in which the said monies are raised-And every denomina[t]ion of christians, demeaning themselves peaceably, and as good Subjects of the Commonwealth, shall be equally under the protection of the Law: And no subordination of any one sect or denomination to another shall ever be established by law. ${ }^{66}$

This final text routinized, and raised to constitutional status, the traditional tithing system, and outlawed some of the hard-fought concessions that Baptists, Anglicans, and other dissenters had secured through litigation in the prior two decades. As Samuel Eliot Morison writes in his definitive early study: "Article III was even less liberal than [the colonial] system, for instead of exempting members of dissenting sects from religious taxation, it merely gave them the privilege of paying their taxes to their own pastors. Unbelievers, nonchurch goers, and dissenting minorities too small to maintain a minister had to contribute to Congregational worship. The whole Article was so loosely worded as to defeat the purpose of the fifth paragraph [guaranteeing the equality of all sects and denominations]. Every new denomination that entered the Commonwealth after 1780, notably the Universalists and Methodists, had to wage a long and expensive lawsuit to obtain recognition as a religious sect. .. . [A] subordination of sects existed in fact." ${ }^{67}$

Article III was not without its own concessions, however. The tithe collection system was now to be local and "voluntary" rather than state-wide- allowing Boston and, later, other townships to forgo mandatory tithing and have churches muster their own support through tithes, tuitions, or pew rents. Religious societies could now contract individually with their own minister - presumptively allowing them to pay their tithes directly to their chosen minister rather than to a potentially capricious town treasurer. Local townships and religious societies could now participate in the choice of their community minister, rather than be automatically saddled with a congregationalist minister. This provision "had some unexpected results. Several of the towns and parishes, which thereby were given the exclusive right to elect their ministers ... . were converted to Unitarianism and settled

\footnotetext{
66 Ibid., 45.

${ }^{67}$ Morison, "The Struggle," 371.
} 
Unitarian pastors over old Calvinist churches." ${ }^{68}$ And the provision that no religious sect or denomination was to be subordinated to another was the first formal statement in Massachusetts history of religious equality before the law not only for individuals but also for groups.

On March 2, 1780, the convention put the final draft of the constitution before the people for ratification. Eighteen hundred copies of the constitution were printed and sent out-and were read from pulpits and lecterns, and posted in town halls throughout the state. Surprisingly, no newspaper of the day ran copies of the draft constitution, a familiar technique used by others states to ensure wide dissemination. The convention also sent out a committee report that explained the rationale of the constitution and encouraged the people's ratification of the same. The committee report dealt directly with Article III, saying:

68 Ibid., 375. 
[W]e have, with as much Precision as we were capable of, provided for the free exercise of the Rights of Conscience: We are very sensible that our Constituents hold those Rights infinitely more valuable than all others; and we flatter ourselves, that while we have considered Morality and Public Worship of GOD, as important to the happiness of Society, we have sufficiently guarded the rights of Conscience from every possible infringement. This Article underwent long debates, and took Time in proportion to its importance; and we feel ourselves peculiarly happy in being able to inform you, that the debates were managed by persons of various denominations, it was finally agreed upon with much more unanimity than usually takes place in disquisitions of this Nature. We wish you to consider the Subject with Candor, and Attention. Surely it would be an affront to the People of Massachusetts-Bay to labour to convince them, that the Honor and Happiness of a People depend upon Morality; and that the Public Worship of GOD has a tendency to inculcate the Principles thereof, as well as to preserve a people from forsaking Civilization, and falling into a state of Savage barbarity. ${ }^{69}$

The people of Massachusetts did give the draft their full "Candor and Attention." Those that voted for ratification - constituting less than $5 \%$ of the population ${ }^{70}$ - rejected the controversial Article III on religious taxes, and perhaps Chapters II and VI on religious test oaths as well, while approving the rest of the constitution. Of the 290 eligible townships, 188 sent in returns that have survived. ${ }^{71}$ The clerks kept close tallies on the votes for the controversial Article III. Article III "fell some 600 votes short of the necessary two-thirds majority for ratification"- with the popular vote in favor standing at 8865-6225. ${ }^{72}$ Though the individual township tallies were less closely kept for other provisions, it also appears that the provisions of Chapter II and VI requiring the Governor to be a Christian and to profess his adherence to the same in a solemn oath also did not garner sufficient two-thirds support. ${ }^{73}$ Nevertheless, members of the convention- out of ignorance of the exact numbers of votes, or out of manipulation of the same- treated the constitution as fully ratified.

On June 16, 1780, James Bowdoin, the President of the Convention, announced, without caveat, that the entire Constitution had garnered the requisite two-thirds vote. On October 25, 1780, the Constitution went into effect, the first day after ratification that the General Court sat. Among the first acts of the General Court was to pledge its support for

69 Journal, Appendix III, at 218.

70 Arthur Lord, "Some Objections to the State Constitution, 1780," Massachusetts Historical Society 50 (1917): 54 , at 55, indicates a state population of 378,000 ; the 15,090 who voted constitute $3.99 \%$ of that population. Morison, "The Struggle," 366 puts the population of Massachusetts proper at c. 307,000; the 15,090 who voted constitute $4.92 \%$ of that population.

${ }^{71}$ Morison, "The Struggle," 364-365.

72 Taylor, ed., Documents, 113. The Township returns are included in Handlin, Popular Sources. 475-932.

73 Taylor, ed., Documents, 113. 
religious liberty: "Deeply impressed with a sense of the importance of religion to the happiness of men in civil society to maintain its purity and promote this efficacy, we shall protect professors of all denominations, demeaning themselves peaceably and as good subjects of the Commonwealth, in the free exercise of the rights of conscience. . . .74

\section{John Adams AND the Massachusetts Model of Religious Liberty}

John Adams was both eclectic and pragmatic in crafting the religion clauses of the Massachusetts Constitution. This was part of the reason for his success. Though a Christian believer of Puritan extraction, Adams eschewed rigorous denominational affiliation or rigid doctrinal formulation. ${ }^{75}$ While in Philadelphia for the sessions of Congress, for example, Adams attended services in Presbyterian, Anglican, Catholic, Quaker, Baptist, and Methodist churches alike. ${ }^{76}$ When Benjamin Rush later pressed him about his religious affiliation, Adams wrote: "Ask me not ... whether I am a Catholic or Protestant, Calvinist or Arminian. As far as they are Christians, I wish to be a fellow-disciple with them all."77 Though a fierce American patriot, Adams knew the value of history and comparative politics. Much of his three volume Defense of the Constitutions of Government in the United States of America (1788), among other political writings, was devoted to sifting ancient, medieval, and early modern Western polities for useful lessons on the best construction of authority and the best protection of liberty. Many of his letters and other informal writings are chock full of favorable references to Greek, Roman, Catholic, Protestant, and Enlightenment writers alike. Though a vigorous moralist, Adams offered his constitutional formulations without "a pretence of miracle or mystery." Any persons "employed in the service of forming a constitution," he wrote, cannot pretend that they "had interviews with the gods, or were in any degree under the inspiration of Heaven." "[G]overnments [are] contrived merely by the use of reason and the senses." Constitutions "are merely experiments made on human life and manners, society and government."78 There will always be "a glorious uncertainty in the law."79

In his constitutional experiment, Adams chose to balance the establishment of a public religion with the freedom of many private religions. This was, in part, a pragmatic choice. Adams knew that the congregationalists would insist on their establishment, and that the dissenters would insist on their freedom. He sought to respect and protect both interests

\footnotetext{
${ }^{74}$ Reprinted in ibid., 162-165, at 164.

${ }^{75}$ For Adams' Puritan devotion, see esp. his Dissertation on the Canon and the Feudal Law, in Adams, Works, 3:451-456, and more generally Page Smith, John Adams, 2 vols. (Garden City: Doubleday, 1962); Catherine Drinker Bowen, John Adams and the American Revolution (Boston: Little, Brown, 1950), $26 \mathrm{ff}$.

${ }^{76}$ See diary entries, in ibid., 2:364, 378, 380, 382, 392, 393, 395, 400, 401, 404. See also Letter to Benjamin Rush, April 18, 1808, in The Spur of Fame, 106-107: "Bigotry, superstition and enthusiasm on religious subjects I have long since set at defiance. I have attended public worship in all countries and with all sects and believe them all much better than no religion, though I have not thought myself obliged to believe all I heard." See further Letter to Benjamin Rush, August 28, 1811, in ibid., 191-195, at 193: "it is notorious enough that I have been a churchgoing animal for seventy-six years, i.e., from the cradle."

${ }^{77}$ Letter to Benjamin Rush, January 21, 1810, in ibid., 9:626, 627.

78 Defense of the Constitutions, in Adams, Works, 4:292-293, 297.

${ }^{79}$ Letter to Josiah Quincy, February 9, 1811, Adams, Works, 9:629-632, at 630.
} 
by combining what he called a "tempered" religious freedom with a "slender" religious establishment. ${ }^{80}$ But this was also, in part, a principled choice. Adams was convinced that the establishment of one common public religion among a plurality of freely competing private religions was essential to the survival of society and the state. We must certainly begin "by setting the conscience free," Adams wrote. For "when all men of all religions consistent with morals and property, shall enjoy equal liberty, ... and security of property, and an equal chance for honors and power ... we may expect that improvements will be made in the human character, and the state of society." ${ }^{81}$ But we must just as certainly begin by "setting religion at the fore and floor of society and government," Adams wrote. "Statesmen may plan and speculate for liberty, but it is religion and morality alone which can establish the principles upon which freedom can securely stand." 82 A common "religion and virtue are the only foundation, not only of republicanism and of all free government, but of social felicity under all governments and in all the combinations of human society."83 "Without religion, this world would be something not fit to be mentioned in polite companyI mean hell." 84

\section{A. The Liberty of Private Religions}

In the 1780 Massachusetts Constitution, Adams dealt rather briefly with the liberty of conscience and the free exercise of religion. He had already stated several times his devotion to the protection of such private religious rights, calling them "indisputable, unalienable, indefeasible, [and] divine." 85 He had praised the sagacity and sacrifice of his Protestant forebearers in securing such rights for themselves and their posterity. ${ }^{86}$ And he saw both the necessity and utility of the continued protection of these rights for all religious groups. As he wrote in the spring of 1780 , "our honest and pious Attention to the unalienable Rights of Conscience is our best and most refined Policy, tending to conciliate the Good Will, of all the World, preparing an Asylum, which will be a sure Remedy against persecution in Europe, and drawing over to our Country Numbers of excellent Citizens." ${ }^{87}$

In the preamble to the 1780 Massachusetts Constitution, Adams spoke of "the power of the people of enjoying in safety and tranquility their natural rights, and the blessings of life," and "the right of the people to take measures necessary for their safety, prosperity and happiness." These words were largely repeated in Article I of the Declaration of Rights: "All men are born free and equal, and have certain natural, essential, and unalienable rights; among which may be reckoned the right of enjoying and defending their Lives and Liberties;

\footnotetext{
${ }^{80}$ Quoted by McLoughlin, New England Dissent, 560. See discussion in Edwin S. Gaustad, "Colonial Religion and Liberty of Conscience," in Peterson and Vaughan, eds., The Virginia Statute, 23-42, at 39.

${ }^{81}$ Adams, Works, 8:232.

82 Letter to Abigail Adams (1775), quoted and discussed in Edwin S. Gaustad, A Religious History of America (New York: Harper \& Row, 1966), 127.

${ }^{83}$ Letter to Benjamin Rush, August 28, 1811, in Adams, Works, 9:635, 636.

${ }^{84}$ Letter to Thomas Jefferson, April 19, 1817, in ibid., 10:253 at 254.

85 Ibid. 3:452-456.

${ }^{86} \mathrm{lbid}$. See also his long discussion of the rise of religious liberty among European Protestants, in the Defense of the Constitutions, bk. 2.

${ }^{87}$ Letter of May 16, 1780 to Isaac Smith, Sr., quoted by Taylor, Construction, 333-334, n 32.
} 
that of acquiring, possessing and protecting property; in fine, that of seeking and obtaining their safety and happiness." 88

In Article II, Adams tendered more specific protections of religious liberty. "It is the [right as well as the] duty of all men in society, publickly, and at stated seasons to worship the SUPREME BEING, the great Creator and preserver of the Universe. No subject shall be hurt, molested, or restrained, in his person, Liberty, or Estate, for worshipping GOD in the manner and season most agreeable to the Dictates of his own conscience, or for his religious profession or sentiments; provided he doth not Disturb the public peace, or obstruct others in their religious Worship." Article III, at least tacitly, recognized the right to form religious associations, to select one's own minister, and to pay tithes directly to him. Chapter VI included within the ambit of religious freedom the right of Quakers to claim an exemption from the swearing of oaths to which they were "conscientiously opposed."

The freedom of religion, as Adams defined it, was thus rather closely circumscribed. It was, in effect, the right of each individual to discharge divine duties - which divine duties the Constitution helped to define. "It is the right as well as the duty" of each person to worship, Article II states. While a person could worship in "the manner and season most agreeable to the Dictates of his own conscience," such worship, per Article II, had to be directed to God, defined as "the SUPREME BEING, the great Creator and preserver of the Universe." Moreover, such worship, per Article III, had to include "conscientious and convenient" "attendance upon the instructions of ministers" "at stated times and seasons." If a person's conscience dictated another object, order, or organization of worship, it was by definition neither religious nor protected as a constitutional right.

This right to religion was further limited by social demands. Neither the preamble nor Article I lists religion among the "natural rights," those rights held prior to society in the state of nature. Instead, Article II emphasized the social character of religious rights- they are held by "all men in society" and involve "public worship." Each individual's religious rights are limited by the needs of society -- by the need for public peace and for protection of the worship of others, as Article II put it. And each individual's religious rights are subject to the "rights" and "powers" of society -- to mandate church attendance, tithe payments, Christian affiliation, and oath swearing, as Article III and Chapters II and VI put it.89

By comparison with other state constitutions of the day, the Massachusetts Constitution was rather restrained in its protection of private religious freedom. Other states defined liberty of conscience expansively to include the right to choose and change religion, to be free from all discrimination on the basis of religion, to be exempt from a number of general laws that prohibited or mandated conduct to which a religious party or group had scruples of conscience. Many states also defined free exercise rights expansively to include freedom to engage in religious assembly, worship, speech, publication, press, education, travel,

\footnotetext{
${ }^{88}$ Amendment, Art. CVI (1982) rendered "all men" as "all persons" and added: "Equality under the law shall not be denied or abridged because of . . . creed. . . ."

${ }^{89}$ Peters, Massachusetts Constitution, 51-52.
} 
parentage, and the like, without political or ecclesiastical conditions or controls. ${ }^{90}$ Few such protections appear in the 1780 Massachusetts Constitution.

Adams was convinced that such a "tempered" form of religious freedom would bring the best "improvements to the character of each citizen." 11 On the one hand, he believed, following conservative conventions of the day, that to grant too much freedom of religion would only encourage depravity in citizens. ${ }^{92}$ "Man is not to be trusted with his unbounded love of liberty," one preacher put it, "unless it is under some other restraint which arises from his own reason or the law of God- these in many instances would make a feeble resistance to his lust or avarice; and he would pursue his liberty to the destruction of his fellow-creature, if he was not restrained by human laws and punishment."93 The state was thus required to "take mild and parental measures" to educate, encourage, and emulate a right belief and conduct. $^{94}$ On the other hand, Adams believed, following more liberal conventions of the day, that "[c]ompulsion, instead of making men religious, generally has a contrary tendency, it works not conviction, but most naturally leads them into hypocrisy. If they are honest enquirers after truth; if their articles of belief differ from the creed of their civil superiors, compulsion will bring them into a sad dilemma" of choosing between a feigned and firm faith. ${ }^{95}$ The state was thus required to refrain from dictating the exact doctrines, liturgies, and texts of a right religion. This was the balance of religious freedom that Adams struck in crafting the Constitution.

\section{B. The Establishment of Public Religion}

Adams further balanced this "tempered" liberty of private religion with a "slender" establishment of public religion. Adams had nothing but contempt for the harsh establishments of earlier centuries -- those featuring state prescriptions of religious doctrines, liturgies, and sacred texts; state controls of religious properties, polities, and personnel; state persecution of religious heresy, blasphemy, and non- conformity. His 1774 Dissertation on the Canon and Feudal Law was a bitter invective against the "civil and ecclesiastical tyranny" of earlier Catholic and Protestant establishments. His 1788 Defense of the American Constitutions devoted several long chapters to digesting critically the horrors of religious wars, crusades, inquisitions, and pogroms, and the sorry plight of some of his Protestant forebearers.

\footnotetext{
${ }^{90}$ See sources and discussion in my Religion and the American Constitutional Experiment (Boulder/New York/Oxford, 1999), chaps. 2-5.

${ }^{91}$ Adams, Works, 8:232.

92 This emphasis on human depravity, and the need for its restraint, is especially pronounced in Adams' earlier writings, notably his 1788 Defense, bk. 1. Later in his life, Adams tempered this view. See, e.g., his Letter to Thomas Jefferson, April 19, 1817, in Adams, Works, 10:253-255, at 254: "So far from believing in the total and universal depravity of human nature, I believe there is no individual totally depraved. The most abandoned scoundrel that ever existence, never yet wholly extinguished his conscience, and while conscience remains, there is some religion."

${ }^{93}$ Simeon Howard, A Sermon Preached Before the Honorable Council . . of Massachusetts-Bay (Boston: John Bill, 1780), reprinted in Thornton, The American Pulpit, 355-396, at 362-363.

94 Worcestriensis, 452.

95 Ibid., 450.
} 
The established public religion that Adams had in mind was much more "slender," "moderate and equitable" in form - tempered by its own provisions, and by the juxtaposed guarantees of private religious freedom for all. As Adams set out his views in the Constitution, the public religion was to be established (1) ceremonially; (2) morally; and (3) institutionally. It was only the third dimension of the public religious establishment, its institutionalization, that drew controversy.

(1) Ceremonial Establishment. The establishment of public religious ceremonies is reflected especially in the preamble. The preamble refers to the constitution as "a covenant" or "compact" between the people and God: "[T]he whole people covenants with each Citizen, and each Citizen with the whole people, that all shall be governed by certain Laws for the Common good." And again, "the people of the Massachusetts, acknowledging, with grateful hearts, the goodness of the Great Legislator of the Universe, in affording us, in the course of his Providence, an opportunity, deliberately and peaceably, without fraud, violence, or surprize, o[f] entering into an Original, explicit, and Solemn Compact with each other; and of forming a New Constitution of Civil Government for ourselves and Posterity; and devoutly imploring His direction in so interesting a Design, DO agree upon, ordain and establish the following Declaration of Rights and Frame of Government. . . . "

This is a covenant ceremonial liturgy, rooted in the Hebrew Bible and in a New England tradition going back to the Mayflower Compact of $1620 .{ }^{96}$ The nature of the constitution is made clear: it is a "solemn" covenant, with God invoked as witness, judge, and participant. The purposes of the covenant are set forth-to create and confirm the identity of the people (the "peoples" and "citizens of Massachusetts"), their common morals and mores (a devotion to the "common good"), and their cardinal institutions (their rights and frame of government). The ethic of the covenant is defined-featuring "gratitude," "peacefulness," integrity ("without fraud, violence, or surprize"), and prayerful devotion ("devoutly imploring His direction in so interesting a Design").

A variant of this covenant ceremony was the oath-swearing ritual of state officials. Adams wrote into Chapter VI of the Frame of Government the requirement that all state officials must swear a full oath to the constitution and the commonwealth-not just privately, but before the people and their representatives in full assembly. "I, A,B, do declare, that I believe the christian religion, and have a firm persuasion of its truth. . . . ; and I do swear, that I will bear true faith and allegiance to the said Commonwealth . . . so help me God." Adams's insistence on such oaths reflected the conventional view that the oath was "a cement of society" and "one of the principal instruments of government" for it invoked and induced "the fear and reverence of God, and the terrors of eternity." 97 This provision also

\footnotetext{
${ }^{96}$ See esp. Donald S. Lutz, The Origins of American Constitutionalism (Baton Rouge: Louisiana State University Press, 1988). See also my "How to Govern a City on a Hill: The Early Puritan Contribution to American Constitutionalism," Emory Law Journal 39 (1990) 41-64 and my "Blest be the Ties that Bind: Covenant and Community in Puritan Thought," Emory Law Journal 36 (1987): 579-601.

${ }^{97}$ See Payson, "Election Sermon," 529. This was also one reason that Adams wrote into his draft of Chapters I and II that every official must be "of the Christian religion."
} 
reflected Adams' view that the oath of office was a public confirmation of the covenant among God, the people, and their rulers.

These preambulary and oath swearing provisions were not merely a bit of hortatory throat-clearing that preceded the real business of constitutional government. They established favorite ceremonies of the traditional public religion of Massachusetts. In the minds of more conservative Puritan sermonizers and subjects of the day, they raised the traditional image of Massachusetts being "under a solemn divine Probation," ${ }^{98}$ and the image of the magistrate as God's vice-regent, called to exemplify and enforce a godly life. Traditionally, the New England Puritans stressed ambition, austerity, frugality and other virtues because the covenant rendered them agents of God, instruments of God's providential plan. For them to be lax in zeal, loose in discipline, or sumptuous in living would be a disservice to God, a breach of their covenant with God. Such a breach would inevitably bring divine condemnation on the community in the form of war, pestilence, poverty, and other forms of force majeure. Traditionally, The New England Puritans' belief in a "solemn divine probation" also rendered the reformation of society a constant priority. They had to ensure that all institutions and all aspects of society comported with the covenantal ideal. Thus Puritan sermonizers urged their listeners: "Reform all places, all persons and all callings. Reform the benches of judgment, the inferior magistrates. . . Reform the universities, reform the cities, reform the counties, reform inferior schools of learning, reform the Sabbath, reform the ordinances, the worship of God. Every plant which my Father hath not planted shall be rooted up."99 It was this tradition, albeit in a less denominationally and doctrinally rigorous form, that Adams established in the constitution.

Beyond the preamble and the provisions on oath-swearing, the Constitution had a few more scattered evidences of a ceremonial establishment. God is invoked, by name or pseudonym (the "Great Legislator of the Universe," and "Supreme Being") a dozen times. References to the "common" or "public good" appear four more times, as do two further references to divine "blessings" and "privileges." These provisions establishing the public religious ceremonies of Massachusetts are more overt and detailed than those of any other state constitution of the day. All these provisions, save the oath provision, were passed without controversy, or even recorded comment. And they remain unchanged to this day.

(2) Moral Establishment. The moral dimensions of the public religious establishment, implicated by the use of covenant and oath-swearing ceremonies, are set out clearly elsewhere in the 1780 Constitution. Article II of the Declaration of Rights, as Adams formulated it, states: "It is the Duty of all men in society, publickly, and at stated seasons to worship the SUPREME BEING, the great Creator and preserver of the Universe." Article III follows with the reason for this duty: "the happiness of a people, and good order and preservation of civil government, essentially depend upon piety, religion, and morality; and

\footnotetext{
${ }^{98}$ W. Stoughton, New Englands True Interest: Not to Lie (1670), in Perry Miller and Thomas H. Johnson, eds., The Puritans: A Sourcebook of their Writings (New York: Harper \& Row, 1963), 243.

${ }^{99}$ Quoted in Harold J. Berman, "Religious Foundations of Law in the West: An Historical Perspective," Journal of Law and Religion 1 (1983): 3-46, at 30. See also id., "Law and Belief in Three Revolutions," Valparaiso Law Review 18 (1984): 569, 595 Ä97.
} 
... these cannot be generally diffused through a Community, but by the institution of publick Worship of God, and of public instructions in piety, religion, and morality. . . " "100

Adams did not consider these constitutional endorsements of religious morality to be mere platitudes. In Article XVIII of the Declaration of Rights, he rendered adherence to these moral duties integral to the character of public offices and public officials:

A frequent recurrence to the fundamental principles of the constitution, and a constant adherence to those of piety, justice, moderation, temperance, industry, and frugality, are absolutely necessary to preserve the advantages of liberty, and to maintain a free government. The people ought, consequently, to have a particular attention to all those principles, in the choice of their Officers and Representatives, and they have a right to require of their lawgivers and magistrates, an exact and constant observance of them, in the formation and execution of the laws necessary for the good administration of the Commonwealth.

For, as Article VII of the Declaration put it: "Government is instituted for the Common good; for the protection, safety, prosperity, and happiness of the people."

Adams rendered these same moral qualities essential ingredients of education within the state. Chapter $V$ of the Frame of Government provides: "Wisdom, and knowledge, as well as virtue, diffused generally among the body of the people, [is] necessary for the preservation of their rights and liberties." It is thus "the duty of Legislatures and Magistrates in all future generations of the Commonwealth to cherish the interests of literature and sciences, and all seminaries of them; . . . to encourage private societies and public institutions, rewards and immunities, for the promotion of [education]. . . . ; to countenance and inculcate the principles of humanity and general benevolence, public and private charity, industry and frugality, honesty and punctuality in their dealings, sincerity, good humour, and all social affections, and generous sentiments among the people." The same Chapter V confirmed and commended the incorporation of Harvard College, since "the encouragement of arts and sciences, and all good literature, tends to the honor of God, the advantage of the christian religion, and the great benefit of this and other United States of America."

None of these provisions establishing a public religious morality triggered much debate during the constitutional convention, and none of these provisions was amended or emended thereafter. Indeed, the famous Eleventh Amendment of 1833 that purportedly "disestablished religion" in Massachusetts simply repeated the mantra of the moral establishment: that "the public worship of GOD and instructions in piety, religion and morality, promote the happiness and prosperity of a people and the security of a Republican Government."

100 But cf. Amendments, Art. XI (1833) and discussion below. 
To this day, the Massachusetts Constitution on its face establishes both religious ceremonies and religious morality. To be sure, this language has become largely a dead letter in recent generations-its legal revival stymied by a political climate that is indifferent, if not hostile, to public religion, and by a First Amendment interpretation that discourages, if not prohibits, the state's implementation of these provisions. ${ }^{101}$ But even in this climate, the Massachusetts courts have recently used these provisions to uphold the constitutionality of state funding of legislative chaplains and of political oaths ending in "so help me God."102 Today, with the center of gravity of the American religious liberty experiment slowly shifting from the courts to the legislatures, and from the federal government to the states, these long dormant constitutional provisions might well find new life.

(3) Institutional Establishment. It was the third dimension of the established public religion-Article III's establishment of specific religious institutions supported by public taxes-that drew fire in the convention and ratification debates, and eventually was outlawed by the eleventh amendment in 1833. Here, critics charged, the balance between private religious freedom and a public religious establishment tilted too much toward the latter.

It was one thing for the Constitution to establish general public religious ceremonies and to define basic public morals and mores-to encourage "piety, religion, and morality," to endorse the public worship of God, to list the "moral virtues" necessary in a good ruler, to commend schools and colleges that offered religious and moral education, to limit breaches of the peace and interferences in another's religious right, all on the assumption that "the happiness of a people, and the good order and preservation of civil government" depended upon the same. ${ }^{103}$ Such provisions at least left a good deal of religious expression and participation open to voluntary choice and individual accent.

\footnotetext{
101 See Robert A. Schapiro, "Identity and Interpretation in State Constitutional Law," Virginia Law Review 84 (1998): 389-457 for a penetrating discussion of state constitutional law as a source of state identity, and of conflicts between state and federal constitutional law. The most recent First Amendment case to outlaw a Massachusetts statute regarding religion is Larkin v. Grendel's Den, 459 U.S. 116 (1982) (outlawing a statute granting churches and schools the power to veto the issuance of liquor licenses to restaurants within 500 of them; such a statute, "provides a significant symbolic benefit to religion in the minds of some" and "enmeshes churches in the exercise of substantial governmental powers"). Generally, the Massachusetts courts have interpreted the religion clauses in conformity with the First Amendment. See, e.g., Commonwealth v. Nissenbaum, 404 Mass. 575 (1989) (the constitution does not protect religious use of illegal drugs), and cases discussed in the next note.

102 Colo v. Treasurer and Receiver General, 392 N.E. 2d 1195 (1979), consistent with Marsh v. Chambers, 463 U.S. 783 (1983); Commonwealth v. Callahan, 401 Mass. 627 (1988). See also the reflections of an Associate Justice of the Supreme Juridical Court of Massachusetts, Herbert P. Wilkins, "Judicial Treatment of the Massachusetts Declaration of Rights in Relation to Cognate Provisions of the United States Constitution," Suffolk University Law Review 14 (1980): 887-930, at 891-897 and 929-930.

${ }^{103}$ Adams put it: "Happiness, whether in despotism or democracy, whether in slavery or liberty, can never be found without virtue. The best republics will be virtuous, and have been so; but we may hazard a conjecture, that the virtues have been the effect of the well-ordered constitution, rather than the cause. And, perhaps, it would be impossible to prove that a republic cannot exist even among highwaymen, by setting one rogue to watch another; and the knaves themselves may in time be made honest men by the struggle." Adams, Works, 6:219.
} 
It was quite another thing, however, for the Constitution to institute religious practices by law - to require persons to attend a preferred form of public worship, to compel them to pay tithes in support of ministers and teachers, to force them to incorporate themselves into state-registered religious societies, and to require them to be faithful in their attendance at worship lest their tithes be diverted or their societies dissolved. For many, such an establishment crossed the line from gentle patronage to odious persecution.

a. Criticisms. During the constitutional ratification debates in 1780 , critics issued a torrent of objections against Article III.

A large group of critics charged that Article III's establishment of public religious institutions contradicted the liberties of private religions guaranteed in Article II. ${ }^{104}$ The return of the town of Dartmouth put it thus:

It appears doubtful in said Articles whether the Rights of Conscience are sufficiently secured or not to those who are really desirous to, and do attend publick Worship, and who are not limited to any particular outward Teacher. . . . we humbly conceive it intirely out of the power of the legislature to establish a way of Worship that shall be agreable to the Conceptions and Convictions of the minds of the individuals, as it is a matter that solely relates to and stands between God and the Soul before whose Tribunal all must account each one for himself. ${ }^{105}$

A second group of critics retorted that the happiness of a people and the good order and preservation of civil government did not, as a matter of historical fact, depend upon piety, religion, and morality. ${ }^{106}$ The Return of Town of Natick put it well:

When both antient History and modern authentik information concur to evince that flourishing civil Governments have existed and do still exist without the Civil Legislature's instituting the publick Christian worship of God, and publick Instruction in piety and the Christian,--but that rather wherever such institutions are fully [executed] by the civil authority have taken place among a people instead of essentially promoting their happiness and the good order and preservation of Civil Government, it has We believe invariably promoted impiety, irreligion, hypocrisy, and many other sore and oppressive evils. ${ }^{107}$

\footnotetext{
104 See, e.g., The Returns of New Salem, in Handlin, Popular Sources, 482; Town of Shutesbury, 597; Town of Ashby, 633; Town of Sherborn, 674; Town of Westford, 682-683; Return of Buxton, 731; Town of Petersham, 855 and Return of Ashby, in Taylor, ed., Documents, 151-152.

${ }^{105}$ Return of Dartmouth, in Handlin, Popular Sources, 509-510.

106 See esp. Peters, The Massachusetts Constitution, 33-35.

${ }^{107}$ Return of Westford, in Handlin, Popular Sources, 681, 682
} 
A third group of critics acknowledged the public utility of piety, morality, and religion, but thought that such an institutional establishment would jeopardize both religion and the state. The Return of the Town of Petersham put it thus:

We grant that the Happiness of a People and the good Order and preservation of Civil Government Greatly Depends upon Piety, Religion, and Morality. But we Can by no Means Suppose that to Invest the Legislature or any Body of men on Earth with a power absolutely to Determine For others What are the proper Institutions of Divine Worship and To appoint Days and seasons for such Worship With a power to impose and Indow Religious Teachers and by penalties and punishments to be able to Enforce an Attendance on such Publick Worship or to Extort Property from any one for the Support of what they may Judge to be publick Worship Can have a Tendency to promote true piety Religion or Morality But the Reverse and that such a Power when and where Ever Exercised has more or Less Been an Engine in the Hands of Tyrants for the Destruction of the Lives Liberties and Properties of the People and that Experience has abundantly Taught Mankind that these are Natural Rights which ought Never to be Delegated and Can with the greatest propriety be Exercised by Individuals and by every Religious Society of men." 108

A fourth group of critics believed that to institute such a mild establishment would inevitably lead to more odious forms. A pamphleteer named Philanthropos puts this "slippery slope" argument well:

Perhaps it will be said that the civil magistrate has a right to oblige the people to support the ministers of the gospel, because the gospel ministry is beneficial to society. [But if so] it will follow, by the same law, that he may adopt any of the maxims of the religion of Christ into the civil constitution, which he may judge will be beneficial to civil society ... if magistrates may adopt any the least part of the religion of Christ into their systems of civil government, that supposes magistrates to be judges what parts shall be taken, and what left; power, then which nothing be more dangerous, to lodged in the hands of weak and fallible men. ${ }^{109}$

A fifth group of critics repeated and amplified Isaac Backus' charge that Article III constituted another species of taxation without representation - now in the religious sphere. As the Return of Ashby put it: "Religeous Societys as such have no voice in Chusing the

${ }^{108}$ Return of Petersham, in ibid., 855.

${ }^{109}$ Continental Journal, April 6, 1780, quoted in Peters, The Massachusetts Constitution, 82. See also Return of the Town of Westford in Handlin, Popular Sources, 682-683. 
Legeslature, the Legeslature therefore have no right to make law binding on them as such; every religeous Society, as such, is intirely independent on any body politick, the Legeslature having therefor no more right to make laws Binding on them, as such, then the Court of Great Britton have to make Laws binding on the Independent states of America." Indeed, the same Return commented later, "to invest their Legeslature with power make Laws that are binding on Religious Society . . . is as much to say we will not have Christ to reign over us that the Laws of this Kingdom are not sufficient to govern us, that the prosperity of this Kingdom is note equally important with the Kingdoms of this world. . . ."110

A sixth group of critics argued that Article III's final guarantee of equality of all denominations simply contradicted the prior provisions on state tax support for some denominations. If "all religious sects or denominations peaceably demeaning themselves" are equal before the law, why are some supported by taxes and others not? Why are all required to register themselves, while others cannot? True religious liberty, critics argued, would leave the "several religious societies of the Commonwealth, whether corporate or incorporate" to their own peaceable devices. It would grant them "the right to elect their pastors of religious teachers, to contract with them for their support, to raise money for erecting and repairing houses for public worship, for the maintenance of religious instruction, and for the payment of necessary expenses."111

b. Support. John Adams had not drafted the controversial Article III. Though he voted for it in the convention, he offered little by way of apologia for it. A number of other theologians and jurists of the day, however, rose to the defense of Article III.

One group of proponents, comprised of congregationalist ministers, invoked traditional "theocratic" arguments for such an institutional establishment. One writer argued that since civil government is God's creation, it would "counter the divine command to provide for worship and the spiritual edification of the people but refuse to support religious institutions."112 Others argued that outlawing the state collection of tithes would "deprive a respectable part of the people of the state of the privilege of discharging their duty to God in a way that they judge to be most agreeable to his will."113 Others issued self-serving jeremiads, predicated on the covenantal language of the preamble, warning that "if the people and their representatives withhold their support of God's church, God will withhold His support of them, and raine down his woeful vengeance."114 Such arguments had been constant and cogent in the more homogeneous and integrated civil and religious communities of seventeenth century Puritan New England. In the more pluralistic and atomistic communities of the later eighteenth century, they carried far less force.

\footnotetext{
${ }^{110}$ Quoted in Taylor, ed., Documents, 151-152.

111 Ibid.

112 Boston Independent Chronicle, February 10, 1780, quoted by Charles H. Lippy, "The 1780 Massachusetts Constitution: Religious Establishment or Civil Religion?" Journal of Church and State 20 (1978): 533-549, at 539-540. See also Howard, Election Sermon, 13-15.

113 Irenaeus, Independent Ledger (April 11, 1780), quoted in Morison, "The Struggle," 380.

114 Abel Holmes, A Sermon Preached at Brattle Street Church in Boston (Boston: Young \& Minns, 1799), 17-18.
} 
A second group of proponents thought such an institutional establishment was an inevitable and innocuous act of a political majority seeking to promote the common good and the personal happiness of all subjects. Boston, which itself did not establish religious institutions, nonetheless supported Article III, arguing in its Return:

Though we are not supporting the Kingdom of Christ, may we not be permitted to Assist civil society by an adoption, and by the teaching of the best act of Morals that were ever offered to the World? To object to these Morrals, or even to the Piety and Religion we aim to inculcate, because they are drawn from the Gospel, must appear very singular to an Assembly generally professing themselves Christians. Suspend all provision for the inculcation of morality, religion, and Piety, and confusion and every evil work may be justly dreaded. ${ }^{115}$

A third group of proponents argued that tithing and other forms of state support for religious institutions would ultimately serve to keep the state small and efficient. Congregationalist preacher, Joseph McKeen, put this well:

But in proportion as the principles, inculcated by the religion of Jesus Christ, prevail in the minds of a people, the number of crimes will be diminished, truth and justice will be maintained, kind and friendly offices will be multiplied, and happiness will be diffused through society. Were the benevolence of the gospel imbibed by all the members of the community, no human laws, nor officers of justice, would be necessary to compel them to do their duty, nor to restrain one from injuring another; and were their temper and conduct generally formed and regulated by it, civil rulers would need to exercise but little power to preserve tranquility in the state. The more, therefore, that the principles of piety, benevolence, and virtues are diffused among a people, the milder may their government and laws be, and the more liberty are they capable of enjoying, because they govern themselves. But if there be little or no regard to religion or virtue among a people, they will not govern themselves, nor willingly submit to any laws, which lay restraint upon their passions; and consequently they must be wretched or be governed by force: they cannot bear freedom; they must be slaves.

For McKeen, therefore, the benefits of a "mild" institutional establishment of religion outweighed its risks - at least for the time being. "The wise institutions of our forefathers, the schools which they established for the education of youth, the provision which they made for the public worship of God, and a religious observance of the Christian Sabbath, have doubtless contributed very much to the tranquil state in which our country is at this day. Let

${ }^{115}$ Full quote in Taylor, ed., Documents, 148-150, with quote on 150 
us not discard these institutions, before we are certain that we have got something better to substitute in their room."116

These and other arguments were combined in Theophilus Parsons' lengthy defense of the utility and necessity of establishing religious institutions in Massachusetts. Parsons, already famous for penning the 1778 Essex Result, had also been a member of the seven member ad hoc committee that had redrafted Article III during the heated convention debate in early November, 1779. He was later appointed Chief Justice of the Massachusetts Supreme Juridical Court, and had several occasions to enforce its provisions against detractors. In the case of Barnes v. Falmouth (1810), he offered "a diligent examination" of the "the motives which induced the people to introduce into the Constitution a religious establishment, the nature of the establishment introduced, and the rights and privileges it secured to the people, and to their teachers."117

Parsons first argued for the necessity and utility of maintaining religion in a civil society and government. In a nutshell, he argued that the happiness of citizens is the goal of government; morality and virtue are essential ingredients to the achievement of happiness; religion and faith are essential wellsprings of morality and virtue; and thus government must support religion and faith. "The object of a free civil government is the promotion and security of the happiness of the citizens," he wrote, invoking and discussing several provisions of the Constitution.

These effects cannot be produced but by the knowledge and practice of our moral duties, which comprehend all the social and civil obligations of man to man, and of the citizen to the state. If the civil magistrate in any state could procure by his regulations a uniform practice of these duties, the government of that state would be perfect. To obtain that perfection, it is not enough for the magistrate to define the rights of several citizens, as they are related to life, liberty, property, and reputation, and to punish those by whom they may be invaded. Wise laws, made to this end, and faithfully executed, may leave the people strangers to many of the enjoyments and of civil and social life, without which their happiness will be extremely imperfect. Human laws cannot oblige to the performance of the duties of imperfect obligation; as the duties of charity and hospitality, benevolence and good neighborhood; as the duties of resulting from the relation of husband wife, parent and child; of man to man, as children of a common parent; and of real patriotism, by influencing every citizen to love his country, and to obey all of its laws. These are moral duties, flowing from the disposition of the heart, and not subject to the control of human legislation.

\footnotetext{
116 Joseph McKeen, A Sermon Preached on the Public Fast in the Commonwealth of Massachusetts (Salem: Thomas C. Cushing, 1793), 17-21.

117 Barnes v. Falmouth, 6 Mass. 401, 404 (1810) (Barnes, C.J.), reprinted with revisions as Theophilus Parsons, Defence of the Third Article of the Massachusetts Declaration of Rights (Worcester, 1820).
} 
Neither can the laws prevent, by temporal punishments, secret offences, committed without witness, to gratify malice, revenge, or any other passion by assailing the most inestimable rights of others. For human tribunals cannot proceed against any crimes, unless ascertained by evidence; and they are destitute of all power to prevent the commission of offences, unless by the feeble examples exhibited in the punishment of those who may be detected.

Civil government, therefore, availing itself only of its own power, is extremely defective; and unless it could derive assistance from some superior power, whose laws extend to the temper and disposition of the human heart, and before whom no offence is secret, wretched indeed would be the state of man under a civil constitution of any form. The most manifest truth has been felt by legislators in all ages; and as man is born, not only a social, but a religious being, so, in the pagan world, false and absurd systems of religion were adopted and patronized by the magistrate, to remedy the defects necessarily existing in a government merely civil. ${ }^{118}$

Having demonstrated the necessity and utility of religion generally for civil society and government, Parsons then turned to the reasons for state support of Christian institutions in particular-in effect, combining the arguments of Joseph McKeen and the Return of Boston. "[T]he people of Massachusetts, in the frame of their government, adopted and patronized a religion, which, by its benign and energetic influences, might cooperate with human institutions, to promote and secure the happiness of the citizens, so far as it might be consistent with the imperfections of man. In selecting a religion, the people were not exposed to the hazard of choosing a false and defective religious system. Christianity had long been promulgated, its pretensions and excellences well known, and its divine authority admitted. This religion was found to rest on the basis of immortal truth; to contain a system of morals adapted to man, in all possible ranks and conditions, situations and circumstances, by conforming to which he would be meliorated and improved in all the relations of human life; and to furnish the most efficacious sanctions, by bringing to light a future state of retribution. And this religion, as understood by Protestants, tending, by its effects, to make every man submitting to its influence, a better husband, parent, child, neighbor, citizen, and magistrate, was by the people established as a fundamental and essential part of their constitution."119

Parsons then moved to answer criticisms that the institutionalization of religion mandated by Article III was "inconsistent, intolerant, and impious."120

\footnotetext{
118 Ibid., 404-405.

119 Ibid., 405.

120 Ibid., 405, 408.
} 
First, Parsons argued, "the manner in which this establishment was made, is liberal, and consistent with the rights of conscience on religious subjects. As religious opinions, and time and manner of expressing the homage due to the Governor of the universe, are points depending on the sincerity and belief of each individual, and do not concern the public interest, ... the second article . . . guards these points from the interference of the civil magistrate ... for every man, whether Protestant or Catholic, Jew, Mahometan, or Pagan." ${ }^{121}$

It is perfectly consistent for the state to maintain these guarantees of liberty of conscience for all and to "provide for the public teaching of the precepts of Protestant Christians to all the people" by collecting tithes to support their ministers and churches. To object that this is a violation of conscience, Parsons wrote, is "to mistake a man's conscience for his money," and to deny the state the right of collecting taxes from those whom it represents.

But as every citizen derives the security of his property, and fruits of his industry, from the power of the state, so, as the price of this protection, he is bound to contribute, in common with his fellow-citizens, for such public uses, as the state shall direct. And if any individual can lawfully withhold his contribution, because he dislikes the appropriation, the authority of the state to levy taxes would be annihilated; and without money it would soon cease to have any authority. But all moneys raised and appropriated for public uses, by any corporation, pursuant to powers derived from the state, are raised and appropriated substantially by the authority of the state. And the people, in their constitution, instead of devolving the support of public teachers of on the corporations, by whom they should be elected, might have directed their support to be defrayed out of the public treasury, to be reimbursed by the levying and collection of state taxes. And against this mode of support, the objection of an individual, disapproving of the object of the public taxes, would have the same weight it can have against the mode of public support through the medium of corporate taxation. In either case, it can have no weight to maintain a charge of persecution for conscience' sake. The great error lies in not distinguishing between liberty of conscience in religious opinions and worship, and the right of appropriating money by the state. The former is an unalienable right; the latter is surrendered to the state, as the price of protection. ${ }^{122}$

\footnotetext{
121 lbid., 405-406.
}

122 lbid., 407-408. 
Second, Parsons argued, the notion that support for religious institutions was intolerant of the non-religious fails to recognize the great public benefits that support of religious institutions brings them. "The object of public religious instruction is to teach, and to enforce by suitable arguments, that practice of a system of correct morals among the people, and form and cultivate reasonable and just habits and manners; by which every man's person and property are protected from outrage, and his personal and social enjoyments promoted and multiplied. From these effects every man enjoys the most important benefits; and whether he be, or be not, an auditor of any public teacher, he receives more solid and permanent advantages from the public instruction, than the administration of justice in courts of law can give him. The like objection may be made by any man to the support of public schools." 123

c. Constitutional Solutions. Such arguments proved sufficient to defend Article III for more than half a century. This was the balance that Adams's dialectical model of religious liberty seemed to demand. All faiths were free, and it was up to individuals to devise their own religious institutions and practices in a manner they found convenient. One faith was fixed, and it was up to the state to devise its religious institutions and practices in manner it found expedient. To leave private religious faiths uncontrolled would only encourage human depravity. To leave the public religious faith unsupported would only encourage social fragmentation. Hence the need to add to a ceremonial and a moral establishment a more robust institutional establishment of the public religion.

However convincing such arguments might have been in theory, they ultimately proved unworkable in practice. In the fifty-three years of its existence, Article III "was fruitful in lawsuits, bad feeling, and petty prosecution."124 Both the casuistry and the clumsiness of the tithing and registration system were exposed in litigation. Resentment at Article III only increased as the religions of Massachusetts liberalized and pluralized-and the former congregational churches were splintered into an array of trinitarian and unitarian forms. ${ }^{125}$ Eventually, detractors so outnumbered proponents that the Massachusetts Constitution was amended. In 1833, Amendment, Article XI outlawed the institutional establishment of the public religion, even while explicitly preserving the ceremonial and moral establishment:

As the public worship of GOD and instructions in piety, religion and morality, promote the happiness and prosperity of a people and the security of a Republican Government;-Therefore, the several religious societies of the Commonwealth, whether corporate or incorporate, at any meeting legally warned and

\footnotetext{
${ }^{123}$ Ibid., 408-409. See also the conclusion of Lippy, "The Massachusetts Constitution," 534-535: Article III did not establish Puritan congregationalism but "providing public support for religious institutions was seen as a way to promote political stability and social cohesion by guaranteeing that individuals would receive instruction in moral principles, rooted in the common religious sensibilities of the people, which would make them good citizens. ..."

${ }^{124}$ Morison, Constitutional History, 24-25.

125 See the careful sifting of this case law in McLoughlin, New England Dissent, 636-659, 1084-1106, 1189-1284, with summaries in William G. McLouglin, "The Balkcom Case (1782) and the Pietist Theory of Separation of Church and State," William \& Mary Quarterly, 3d ser. 24 (1967): 267-283; Cushing, "Notes on Disestablishment in Massachusetts."
} 
holden for that purpose, shall ever have the right to elect their pastors of religious teachers, to contract with them for their support, to raise money for erecting and repairing houses for public worship, for the maintenance of religious instruction, and for the payment of necessary expenses: And all persons belonging to any religious society shall be taken and held to be members, until they shall file with the Clerk of such Society, a written notice declaring the dissolution of their membership, and thenceforth shall not be liable for any grant or contract, which may be thereafter made, and denominations demeaning themselves peaceably and as good citizens of the Commonwealth shall be equally under the protection of the law; and no subordination of one sect or denomination to another shall every be established by law.

Subsequent amendments of 1855, 1917, and 1974 closed the door tightly against any form of state fiscal and material aid to religious institutions and endeavors -- provisions which the Massachusetts courts have enforced with great alacrity. ${ }^{126}$

\section{CONCLUSIONS}

In the preface to his Defense of the Constitutions of Government in the United States of America of 1788, John Adams wrote boldly: "The people in America have now the best opportunity and the greatest trust in their hands, that Providence ever committed to so small a number, since the transgression of the first pair; if they betray their trust, their guilt will merit even greater punishment than other nations have suffered, and in the indignation of Heaven." "The United States have exhibited, perhaps, the first example of governments erected on the simple principles of nature; and if men are now sufficiently enlightened to disabuse themselves of artifice, imposture, hypocrisy, and superstition, they will consider this event as a [new] era in history. Although the detail of the formation of the American governments is at present little known or regarded either in Europe or in America, it may hereafter become an object of curiosity" for it is "destined to spread over the northern part of that whole quarter of the globe." Indeed, "[t]he institutions now made in America will not wholly die out for thousands of years. It is of the last importance, then, that they should begin right. If they set out wrong, they will never be able to return, unless it be by accident to the right path."127

\footnotetext{
${ }^{126}$ Amendment Art. XVIII (1855) provides that tax "moneys shall never be appropriated to any religious sect for the maintenance exclusively of its own schools." This was superseded by Amendment, Art. XLVI (1917) that provides, in pertinent part, that "no law shall be passed prohibiting the free exercise of religion" and that no tax money was to be paid to religious groups or activities. Amendment XLVI, in turn, was further amended by Amendment, Art. CIII (1974): "No grant, appropriation, use of public money or property or loan of credit shall be made by the Commonwealth or any political subdivision thereof for the purpose of founding, maintaining, or aiding any ... charitable or religious undertaking which is not publicly owned and under the exclusive control of [the Commonwealth]." For summary of the cases, see Wilkins, "Judicial Treatment," 892-894.

${ }^{127}$ Adams, Works, 4:290, 292-293, 298.
} 
Two centuries later, such sentiments prove remarkably prescient. The American framers did begin on the right path of religious liberty, and today we enjoy a remarkable freedom of thought, conscience, and belief as a consequence. American models of religious liberty have had a profound influence around the globe, and their principles now figure prominently in a number of national constitutions and international human rights instruments. ${ }^{128}$

To be sure, as Adams predicated, there has always been "a glorious uncertainty" in the law of religious liberty, and a noble diversity of understandings of its details. This was as true in Adams' day as in our own. In Adams' day, there were competing models of religious liberty more overtly theological than his-whether Puritan, Anglican, Evangelical, or Catholic in inspiration. There were also competing models more overtly philosophical than hiswhether Classical, Republican, Enlightenmentarian, or Whig in inclination. Today, these and other models of religious liberty have born ample progeny, and the rivalries among them are fought out in the courts, legislatures, and academies throughout the land.

Prone as he was to a dialectical model of religious liberty and a federalist system of government, Adams would likely approve of our rigorous rivalries of principle-so long as all rivals remain committed to constitutional ideals of democracy, liberty, and rule of law. But Adams would also likely insist that we reconsider his most cardinal insights about the dialectical nature of religious freedom and religious establishment. Too little religious freedom, Adams insisted, is a recipe for hypocrisy and impiety. But too much religious freedom is an invitation to depravity and license. Too firm a religious establishment breeds coercion and corruption. But too little religious establishment allows secular prejudices to become constitutional prerogatives. Somewhere between these extremes, Adams believed, a society must find its balance.

The balance that John Adams struck in favor of a "mild and equitable establishment" of Protestantism can no longer serve a nation so fully given to religious pluralism. But the balance that the Supreme Court has struck in favor of a complete disestablishment of religion can also no longer serve a people so widely devoted to a public religion and a religious public. Somewhere between extremes, our society must now find a new constitutional balance-with Adams's efforts serving as a noble instruction.

${ }^{128}$ See generally John Witte, Jr. and Johan D. van der Vyver, eds., Religious Human Rights in Global Perspective, 2 vols. (The Hague/London/Boston: Martinus Nijhoff, 1996); John T. Noonan, Jr., The Lustre of our Country: The American Experience of Religious Freedom (Berkeley/Los Angeles/London: University of California Press, 1998). 